\title{
Accountability of Cash-Intensive on Village Funds (Case study in Kendal Village, Sekaran District, Lamongan Regency)
}

\author{
Dewi Kusmaya Sari ${ }^{1}$, Ikhsan Budi Riharjo ${ }^{2}$, Maswar Patuh Priyadi ${ }^{3}$ \\ ${ }^{1,2,3}$ Sekolah Tinggi Ilmu Ekonomi Indonesia (STIESIA) Surabaya, Indonesia \\ dewi.khusmaya1286@gmail.com
}

\begin{abstract}
Accountability is an essential issue in scientific studies and practice in the field of public administration. Accountability in managing village funds has become a demand for the village government, as Law Number 6 of 2014 has been implemented concerning villages. Problems arise when the accountability of village funds' labor- insentive cash is related to the new regulation. This policy requires village funds to be used for cash labor following SKB 4: the minimum wage must reach $30 \%$ of the total development sector sourced from the Village Fund. Therefore, this study aimed to describe and analyze cash accountability for labor in village funds (a case study in Kendal Village, Sekaran District, Lamongan Regency). Qualitative interpretive research was applied with interviews, observation, and documentation from official government documents. Furthermore, this study showed that the village fund accountability in Kendal Village, Sekaran District, Lamongan Regency has gradually implemented participation and transparency principles. The fund had met the wage requirements following SKB 4. The village had to reach $30 \%$ of the total development of the fund. Its implementation was carried out in a self-managed wanner involving workers from the poor, unemployed, and families with malnutrition, as evidenced by the ID card of Kendal villagers. Eventhough they experience obstacles in determining yhe poor's criteria, the budget activity implementer (PKA) tries to apply accountability in the implementation of development based on the cash-insentive principle.
\end{abstract}

Keywords

planning, implementation; administration; cashlaborinsentive reporting

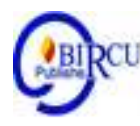

\section{Introduction}

Accountability is a concept that emphasizes the capacity of public sector organizations to provide answers to all parties concerned with the organization. According to Starling (2008), accountability is the ability of public sector organizations to explain actions carried out especially to those in the political system who have been given the authority to carry out assessments and evaluations of the public sector. Public sector institutions are required to prioritize horizontal accountability and vertical accountability in order to create public accountability. The new provision was later emerged that external financial statements that were able to show the performance of the institution (Mardiasmo, 2002).

Based on the Ministry of Villages, Development of Disadvantaged Regions and Transmigration of The Republic of Indonesia in 2015 explained that the government has allocated a phenomenal village budget for a new program/policy. Data from the Ministry 
of Finance of the Republic of Indonesia (Memorandum of Finance), the amount of village funds budgeted by the government for the last 3 (three) years amounted to Rp127.75 T.

Accountability of village funds has been carried out accountable by using the application of village financial system commonly called SISKEUDESA. In the current system of government, the central government has a priority program every year in the implementation of village funds, one of which is the Cash Intensive Program. Cash Intensive Program is a government agenda in the form of empowerment activities of marginalized and poor village communities by emphasizing the utilization of labor, utilization of resources, and utilization of local technology aimed at reducing poverty, increase income, and improve people's prosperity. Article 4 of UU No. 6 of 2014 on Villages, the existence of village arrangements serves to overcome development gaps, advance the economy, and strengthen communities as the subject of development.

All activities related to village development will be carried out independently called "Cash Intensive Program". In addition, the government will integrate social assistance activities in a statement "Cash Intensive Program". All efforts are put in place to boost the village econonomy. Some of the problems that occurred include: the existence of a priority program of village funds, namely Cash Intensive Work, planning in 2018 has been created and confirmed in the form of APBD, but wages have not reached $30 \%$ so it is necessary to make changes in planning and refocusing activities in order to achieve a wage value of $30 \%$ of village funds. Furthermore, it needs to be evaluated on how the accountability report for Cash-Intensive as it is the latest ministerial priority program that has not been done since the existence of village funds in 2015.

Next, Kendal is one of the villages in sekaran sub-district that obtained the third largest village fund allocation of $\mathrm{Rp} 688.728 .000$, - and allocated for $30 \%$ of the wages for cash-intensive amount Rp 187.617.000. Based on the research background that has been described above, the problem in this research is how accountability report accountability Of Cash Intensive Village Fund in Kendal Village Sekaran District Lamongan Regency.

\section{Research Methods}

This type of research is interpretive qualitative research. According to Sugiyono (2012), qualitative research is a research based on the philosophy of postpositivism, necessary to examine the phenomenon of natural object, where the presence of researchers as a key instrument and data collection techniques are triangulation. The location in this research in Kendal Village, Sekaran District, Lamongan Regency in November 2019 where there is a Cash Intensive Village Fund. The object of this research is The Cash Intensive Village Fund Fiscal Year 2018 Kendal Village Sekaran District Lamongan Regency, and the report of the accountability of Cash-Intensive Works in the Village of Kendal District Sekaran Lamongan Regency.

The result of valid and accurate data and information, with in-depth interviews, to informants who are used as sources of information. Informant chosen is in the form of informants who are directly involved in understanding and being able to provide an overview of Cash Intensive, namely 1) Expert Companion of Lamongan Regency, namely as a companion at the district level as a regulatory bearer and program guard from planning to reporting, 2) Village Companion sekaran sub-district, namely as a companion at the sub-district level as a regulatory bearer and program guard from planning to reporting, 3) The Head of Kendal Village, namely as the power of budget users in the implementation and village,4) Treasurer of Kendal Village, namely as the executor of village financial management, 5) Kendal Village Society as the recipient of cash-intensive wages village 
funds, 6) Implementing Budget Activities.

The research object classified as a study unit in this study is the accountability of Cash Intensive Village Fund in Kendal Village, Sekaran District, Lamongan Regency by interviews to resource persons who are key informants in this research. In this study, researchers will discuss about accountability report accountability in accordance with standard implementation procedures as well as measurable output and outcome. Moreover, the data analysis (Sugiyono, 2012), is a process of systematically searching and arrange data obtained from interviews, field records and other materials, so that it can be easily understood and its finding can be informed to others. In this study, the stages of data analysis to determine categories, concepts, themes and patterns and finally perform data analysis.

\section{Results and Discussion}

\subsection{Description of Research Area}

One of the villages in Sekaran Subdistrict, Lamongan Regency, East Java Province, is Kendal Village. The topology of this village is a low area that has an administrative area of $350 \mathrm{Ha}$ and a height of 500 meters above sea level with an average air temperature of $22^{\prime} \mathrm{C}-30^{\prime} \mathrm{C}$. Kendal Village area is quite an easy area in obtaining irrigation sources because it is passed by the Bengawan Solo River that passes through the western village border as well as the Babat Barrage Dam. Then some of the land in Kendal village is used for agricultural land. The occupation of Kendal villagers are farmers, fishermen, carpentry farmers, self-employed, and shorelin out of the country or out of Java Island.

\subsection{Accountability of Cash-Intensive Village Funds}

Accountability in village fund management starts from planning, implementation, administration, reporting and accountability. Village Fund Management is based on the principles contained in the Regulation of the Domestic Minister No. 113 of 2014 concerning Village Financial Management, namely transparent, accountable, participatory and in an orderly and disciplined budget.

\subsection{Planning}

Village community institutions are a forum for village community participation as village government partners and are tasked with empowering village communities, participating in planning and implementing development, and improving village community services. Therefore it is important to empower village community organizations as village government partners in the context of implementing participatory development (Angelia et al, 2020).

Cash Intensive Village Fund in Kendal Village (PKTD) is a village community empowerment activity sourced from village funds for poor and marginal communities that are productive by focusing on resource utilization, labor utilization, and utilization of local technology. This is a direct referral program from the president, which is carried out for all villages in Indonesia.

Kendal village is one of the villages in the sub-district that conducts development planning stages in accordance with the regulation of the domestic minister No. 114 of 2014 and in accordance with the follow-up work plan (RKTL) which is the stages of all planning programs and activities prepared with the Planning Research Council. Medium Term Village Development (RPJMDesa) and then continued with the consideration of the Village Development Work Plan (RKPDesa) consideration budget and village expenditure 
revenue (APBDesa) at the end of December of the year. Village Development Planning (Musrenbangdes). Musrenbangdes is a deliberation forum that discuss various development planning proposals at the village level based on the principle of P3MD (Village Community Participation Development Planning). The implementation of the principle of participation is explained by the Village Head as follows:

"The planning stages start from RPJMDesa, RKPDesa, and APBDesa through discussion and community participation in accommodating all development proposals from the community and in accordance with the needs of the community and proposals funded in accordance with the proposals that are priorities required by the community in the results of mutually agreed discussion and the implementation of discussion carried out in the year running for the next year planning, namely the planning estimation of the 2018 year carried out in 2017 in accordance with the principles of P3MD".( Head of Kendal Village)

In the 2018 Kendal Village Village APB document that has been determined has not included the policy of Cash Intensive Funds at least thirty percent (30\%), then Kendal Village implements changes to the APBD Village document in fiscal year 2018 to adjust the HOK with a minimum value of $30 \%$ of the Village Fund obtained, and carry out the centralization of development activities (Revocusing) and arrange proposals for activities, technical design activities in accordance with the guidelines of Cash-Intensive Village funds, and budget and cost plans.

The centralization of village development activities is based on village meter regulations, development of disadvantaged areas and transmigration No. 19 of 2017. The discussion of village development activities (Revocusing) was on Monday, February 19, 2018 at Kendal Village Hall, Sekaran District, Lamongan Regency. The result of revocusing is:

Table 1. Revocusing village fund activities in fiscal year 2018

\begin{tabular}{clccc}
\hline No & \multicolumn{1}{c}{ Activity Name } & Volume & Value & Wage \\
\hline 1 & Retaining wall (TPT) & $740 \times 1 \times 0.20$ & 252.728 .000 & 72.370 .000 \\
2 & Sports field & $25 \times 25 \times 0.12$ & 126.000 .000 & 30.540 .000 \\
3 & Dam & $2 \times 3 \times 1.50$ & 75.000 .000 & 19.550 .000 \\
4 & Normalization Times & $750 \times 2 \times 1.5$ & 75.000 .000 & 16.247 .000 \\
5 & Pkt & $750 \times 1.50 \times 0.60$ & 50.000 .000 & 48.910 .000 \\
\hline
\end{tabular}

Source: RAB and Kendal Village Design

From the table above, it can be known that the total amount of Village Fund for development activities is Rp578.728.000,- while for the total wage of Rp187.617.000,- in accordance with the provisions of SKB 4 ministers that the total wage of development activities funded by the Village Fund is at least $30 \%$ if calculated $30 \%$ from Rp578.728.000,- is Rp173.618.400,- then the proceeds from revocusing can be ascertained in Kendal village is in accordance with SKB 4 ministers because wages have exceeded $30 \%$ of the total development activities funded by the Village Fund.

\subsection{Implementation}

The implementation in Kendal Village, Sekaran Sub-District of Lamongan Regency is carried out transparently and accountably. The implementation of activities in the Budget Year 2018 village APBD whose financing is sourced from village funds in accordance with the principles of Cash Intensive Village Fund is fully by the Village Budget Activities Implementation Team (PKA), furthermore to support the openness and delivery of information to the community, every implementation of physical activities of village funds 
for cash-intensive work in Kendal village has included a Project Board. The activities conducted at the location at the beginning of work. The Village Budget Activities Implementation Team (PKA) has an obligation to take responsibility for its performance during the implementation of Village Fund activities. Not only were the project boards at the completion stage of development activities installed, but also activity inscriptions containing information starting from the volume of activities, the amount of funds and benefits. This is evidenced by the following interview results:

"The implementation of Cash Intensive Work is carried out by the implementers of budget activities (PKA). We use the project board on every want to carry out the work of the Village Fund in every development activity. There is clearly how much funds and volume at length and breadth, then the benefits for the village and at the end of the work in the inscription containing information about development activities as a means of transaparancy" (Sujarwoko).

The implementation of village fund in fiscal year 2018 in Kendal Village implemented by PKA is through the procurement process of goods and services where the goods and services are carried out before the implementation of development and adjusted to the budget of each activities based on the Lamongan Regent Regulation No.19 of 2015 on the procurement of goods and services. Those who participated in the auction assumed the goods in kendal village are TB Menara 2 with the owner named Gufron susilo and Anugerah Alam with the owner name Purwanto.

The development in the village of Kendal Sekaran sub-district is carried out independently principled on Solid Cash Works where starting materials, tools, workers all come from the village of Kendal itself and in accordance with the results of revocusing development implementation activities are also adjusted to the planning that has been agreed. Before the implementation is done by PKA, the data collection is conducted in advance for the candidates receiving Cash Intensive Work. The data collection on residents who interfere with the unemployment of poor families and families who have malnutrition is proven by ID Card. The second implementation of development activities is a sports field with principles remained on The Cash Intensive. Next, the construction of the village dam. After the village dam work is completed, it was continued by doing normalization using heavy equipment because of the conditions of wide and deep times so that it can not use human resources for agricultural irrigation purposes with the aim of increasing yields for the welfare of the community.

The principle of implementation of Cash Intensive Village Fund In Kendal Village is Inclusive that involves the poor, marginalized, and people with disabilities, as well as participatory from by and for the community of Kendal village with the spirit of mutual cooperation and agreed in deliberation, Transparent and accountable and effective which prioritize activities which have an impact on improving the welfare and purchasing power of the kendal village community as well as the management, care and sustainable preservation.

In terms of the implementation of accountability principles, the implementation of Cash Intensive Village Fund is carried out with a monthly reporting system and reports of each stage of activity. PKA is very instrumental in the implementation of Village Fund activities, especially Cash Intensive Work, and PKA has an obligation to account for its performance during the implementation of Village Fund activities.

The implementation of village finance in Kendal village is based on the principle of village revenue and expenditure. Permendagri No. 20 of 2018 concerning Village Financial Management has regulated the implementation in article 43 which says that the implementation of village financial management is the revenue and expenditure of villages 
through village cash accounts at banks appointed by the Regent / Mayor. All village revenue and expenditures in the framework of implementation are through village cash accounts and all revenue and expenditures are supported by complete and valid evidence. The flow of village funds is transferred from the State General Cash Account (RKUN) to the Regional General Cash Account (RKUD) then to the Village Cash Account (RKD). Village Fund in the transfer trough three stages, that is $40 \%$ of the first stage, $40 \%$ of the second stage and $20 \%$ of the third stage.

The implementation of revenue receipt is the process of receiving and recording the income of Kendal Village, Sekaran District, Lamongan Regency in receiving village funds attaching APBD and design as well as integrity pact and payment request letter (SPP) accompanied by a memorandum namely TB Tower 2 as for the disbursement of the next stage attach a report on the realization of the use of village funds of the previous stage along with other requirements as well as the third stage. This is evidenced by the results of the interview as follows:

"all transactions of funds transfer through RKUN to RKUD and next to the Village Fund Receipt RKD in Kendal Village there are three stages, that is first stage 40\%, second stage $40 \%$ and third stage $20 \%$. The implementation of village financial management is through the bank account appointed by the lamongan regent which is supported by the completeness of first stage, namely APBDesa Rab and design as well as integrity pact and payment request letter (SPP) accompanied by a memorandum from the recommendations from Sekaran Sub District through the Sub-District and attaching the Kendal Village RKP The second stage of the report on the realization of phase one activities, the letter of payment request (SPP) accompanied by a memorandum as well as the third stage "(Treasurer of Kendal Village)

Based on beginning observations, interviews and documents, in the village of Kendal District Sekaran Lamongan regency obtained the conclusion of the implementation prioritized in the field of development and empowerment for Cash Intensive Works. The implementation of village funds in Kendal Village, Sekaran sub-district by PKA, where PKA plays a very important role in this implementation stage. The village government tries to implement transparent principles by installing information boards at the location of activities and in village offices. For the application of accountability principles is by the report of each stage of activities with reference to existing regulations. However, there is limited knowledge about village funds from PKA so there are some reports are late. Then the principle of revenue and expenditure is also completing valid documents and proof.

\subsection{Administration}

The administration stage of Kendal Village is by the Village Treasurer in an accountable. Kendal Village Treasurer must carry out the recording of revenue and expenditure in the General Ledger which is cash, then transactions through banks / transfers are recorded in the Bank Book, payout at the end of each month systematically, and accountable reports. In addition, the Treasurer of Kendal Village conducts an orderly recording of all financial transactions that occur. Administration conducted using General Ledger, Tax Assistance Ledger, and Bank Book (Village Financial Management, 2015).

The Village Treasurer notes that expenditure transactions must be accompanied by complete and valid evidence and recorded correctly. Transactions are recorded with the receipt of spending and then deposited into the SPP definitf until the process of tax collection and payment of SPP so that it will automatically reduce the general cash after the bank cash mutation in the general cash. And after the tax collection is carried out tax deposits after taxes are paid to the State by issuing billing each tax that has been collected 
so that it will automatically be included in the Tax Helper's Book. The Treasurer of Kendal Village also applies the principle of accountability in administration by recording all income and expense transactions in accordance with complete and valid evidence. The interview results are as follows:

"Accountability report is carried out every month. Where the Treasurer does his name closes the book at the end of each month. All income is recorded as well as expenses. Then it is reported to Village Head every month." (Treasurer of Kendal Village)

Based on beginning observations, interviews and documentation, in Kendal Village, the conclusion of administration was obtained by the village financial system (SISKEUDES). The recording of village receipts by the Village Treasurer with a note and receipt and at the time the funds go into the Kendal Village Cash account recorded in the General Ledger, Bank Book, and Income Details Book. Meanwhile, the recording of the expenditure is an interest from the cash of Kendal Village and in accordance with the evidence of valid notes and receipts through a letter of payment request (SPP) and recorded in the General Ledger, Bank Book, and Tax Helper Book. For Financing is recorded in the Financing Details.

Kendal Village Treasurer reports his accountability every month to Village Head no later than 10 months. The Treasurer of Kendal Village also applies the principle of accountability by recording all receipt and expenditure transactions in accordance with valid and complete evidence. The Village Treasurer experienced several constraints in administration such as errors, incompleteness, and untidy related documents or SPJ from the PKA or The Head of division concerned.

\subsection{Reporting and Accountability}

\section{a. Report on Realization of Absorption and Achievement of Village Fund Output}

Kendal Village in delivering the Report on the Realization of Absorbtion and Achievement of Village Fund Output experienced delays in reporting semesters the main cause is the slowness of reports from PKA. The lack of knowledge and understanding and commitment from PKA responsible for managing activities causes reports of activities often late. If PKA is careless when making reporting then it affects the semester report. PKA is late reporting so that it hinders the distribution of village funds in the next stage. The report on the Realization of Absorbtion and Achievement of Village Fund Output in the second semester or end of the year was submitted through consideration with BPD and all government stake holders in Kendal Village and then verified by the district. The obstacles when prepare Report on the Realization of Absorption and Achievement of Village Fund Output in Kendal Village is the inequality of perception of some APIP in lamongan district, namely inspectorate, DPMD, and Village Assistance so as to slow Kaur in completing SPJ.

Based on beginning observations, interviews, and documents in Kendal Village, it

was concluded that the Report on the Realization of Absorption and Achievement of Village Fund Output was delayed. The submission of the report was carried out through consideration with BPD and stake holders in the kendal village government. This reporting stage there are several obstacles faced such as. there is an inequality of perception from some APIP in lamongan district, namely inspectorate, DPMD, and Village Companion so as to slow Kaur in completing SPJ. The cause of the delay was also due to the late report from PKA. Then for the application of accountability also with the openness to the general public. 


\section{b. Village Fund Cash-Intensive Accountability Report}

Kendal Village sub-district now in delivering the Accountability Report realization of the implementation of APBD experienced delays, this is due to the difference in income between APIP, namely Inspectorate, DPMD, and P3MD in lamongan district. Village Fund in Kendal Village is one of the main sources of village income that is quite large and must be accounted for transparently to the community and to the government at a higher level as an institution of authority. Accountability Report on the Realization of Cash-Intensive Implementation of Village Funds was submitted by holding deliberations with BPD attended by the community. Reports are read one by one ranging from planning, use, to percentage realization. Accountability by the village government can be accounted for to all levels of society openly. In this case, the Kendal village government of Sekaran subdistrict it openly to the general public and explained in front of the higher parties and the community in the deliberations of Village Accountability. Openness by provide information to the public in writing with easily accessible information media such as bulletin boards, banners, Billboards and other media. The interview results are as follows:

"Through the Joint Consideration of BPD submitted the Final Accountability Report, from all funds that go into the village account, especially the Village Fund because the Village Fund is the largest fund in the village income. Then an invitation was made and invited by the community that the Village Head will submit a Year-End Accountability Report. If it is agreed and approved by BPD and the community, then just tap the hammer. The result of conseideration is made information boards, banners, billboards and inscriptions as a medium of information that is easily accessed by the community "(Head of Kendal Village)

Based on beginning observations, interviews, and documents in Kendal Village, Sekaran sub-district, it was concluded that the Accountability Report on the Realization of Cash-Intensive Implementation of Village Funds was submitted late to Lamongan Regency. Accountability report is submitted by holding deliberations with BPD and the community. Accountability is also carried out with openness to the public. Transparency and participation are carried out by including the public in reporting accountability and provide information to the public by using media such as billboards and banners. However, in the accountability report there are still some obstacles faced such as frequently changing regulations, as well as SPJ problems.

The village government's understanding of village fund financial management is an important and fundamental aspect that must be had in realizing transparency and accountability of village finances. Accountability of village government can be seen from the stages of planning, implementation, administration and reporting and can be accounted for administratively, technically and legally. Accountability can be seen how the village government manages village finances, especially in village funds and accepts the aspirations of the villagers and how the community participates in supporting the success of the planned program. The information provided to the community is clearly conveyed and equipped with an activity information board to implement the principles of transparency and accountability.

To support the realization of good governance in village implementation, village financial management needs to be organized in accordance with the principles of village financial management. The principles of Village Financial Management as stated in Permendagri No. 20 of 2018 concerning Village Financial Management are transparent, accountable, participatory and orderly manner and budget discipline.

Planning in Kendal Village sub-district has now applied the principle of participation and transparency in accordance with the principles of village finance. Planning with the 
excavation of ideas every RT and Musrenbang in the assessment of the state of Kendal Village attended by BPD and other community leaders. Community participation in village considerations is high and they are enthusiastic in provide ideas or proposals. Information is disseminated through banners and billboards, giving an explanation of the time in Musrenbang.

The timing of the planning of village funds and village budgets in Kendal Village, Sekaran sub-district in accordance with the time limit set out in Permendagri No. 113 Year 2014 on Village Financial Management article 20. And according to the indicative pagu information of the district. The Village Government also experienced obstacles in the planning stage such as the regulation that often changes as well as the existence of SKB 4 Minister that the Village Fund for Cash-Intensive Work So that changes in APBD in February 2018, Revocusing activities in order to achieve 30\% of the wages of development activities for Cash Intensive Work resulting in one activity can't be funded and is planned to be funded the following year. Field survey, related to RAB in accordance with the activities at the Revocusing considerations

The Implementation Stage in Kendal Village, Sekaran sub-district has implemented transparent principles as well as community participation in development. The principle of accountability hasn't been fully implemented by PKA. However, the village government has implemented accountability related to revenue and expenditures in accordance with Permendagri No. 20 of 2018. The village government tries to implement transparent principles by installing information boards at the location of activities and there are also in village offices. The implementation of village development also involves community participation by including the local community as its workers and the PKA is the community as well.

The application of accountability principles by reporting each stage of activities that refers to existing regulations. However, there is still a lack of knowledge from PKA related to the report from PKA. This makes obstacles in the implementation stage, because the human resources of the PKA are inadequate and the lack of commitment from the PKA. So that PKA reporting sometimes terlambta. The principle of revennue and expenditure is carried out by completing complete and valid documents and other evidence. As by attaching the Report on the Realization of Absorption and Achievement of Village Fund Output for the disbursement of funds phase two. The expenditure is accompanied by RKP Kendal Village, RAB, SPP and receipts.

Administration in financial management in Kendal village has applied the principle of accountability and has been in accordance with Permendagri No.20 Year 2018 on Village Financial Management as well as guidelines for implementing guidance and consultation on village financial management. The recording of administration is carried out using the Village Financial System (SISKEUDES). The recording of village receipts is carried out with receipts and at the time the funds go into the Kendal Village cash account recorded in the General Ledger, Village Bank Book, and Income Breakdown Book. While the expenses are recorded by the withdrawal from the cash of Kendal Village and in accordance with the valid evidence and receipts, then recorded in the General Ledger, Village Bank Book, Tax Helper Book. The Village Treasurer also records cash and noncash transactions with valid evidence and completeness. Related to financing transactions are recorded in the Financing Details.

The Treasurer closes the book every month and records all revenue and expenditures and is held accountable for his work by reporting his accountability report every month to the Head of Kendal Village no later than the 10th of the following month. The Village Treasurer also applies the principle of accountability by recording all receipt and 
expenditure transactions in accordance with valid and complete evidence. Although the Village Treasurer experienced problems in administration such as late PKA purchase, errors, incompleteness, and irregularities related to documents or SPJ from PKA or Kaur concerned. Village Treasurer, however, seeks to apply accountability in administration.

Reporting of Village Fund and Realization of APBD Implementation in Kendal Village Sekaran Sub-District has tried to apply the principle of accountability but still not in accordance with the time set by Permendagri No. 20 Year 2018 on Village Financial Management. The principle of accountability is also applied by openness to the public.

The delay in reporting the Report on The Realization of Absorption and Achievement of Village Fund Output is caused by the delay in the report from PKA. The late report from PKA is due to lack of knowledge and understanding and commitment from PKA who is responsible for managing activities. The village government also experienced other obstacles, namely the frequent changes of Permendagri and Permendes, the settlement of SPJ from the kaur concerned and also the recording of assets. So, it makes the report realization of the implementation of APBD late submitted.

Accountability of Cash-Intensive Implementation of Village Funds in Kendal Village has applied the principle of accountability and transparency. Namum accountability realization of the implementation of APBD is still not in accordance with Permendagri No. 20 of 2018 on Village Financial Management due to the submission of reports that are experiencing delays. The submission of the Accountability Report for The Implementation of Cash-Intensive Village Funds experienced a slight delay due to differences of opinion between APIP, namely the inspectorat of Lamongan Regency, DPMD, P3MD as well as other constraints such as frequently changing regulations, as well as problems related to SPJ.

Accountability reports are with openness to the public. The report was presented in a joint consideration with BPD which was attended by the community. The principle of transparency and participation by society in reporting accountability and providing information to the public by using billboards or banners that are easily accessed by the public. This is in accordance with Permendagri No. 113 Year 2014 on Village Financial Management article 40.

\section{Conclusion}

The cash-intensive planning stage in Kendal village, Sekaran District, Lamongan Regency has gradually implemented the principle of participation and transparency. Further, it is already qualified wages in accordance with SKB 4 ministers where the wages of the total development must reach 30\%. However, since the regulation of SKB 4 ministers was issued in February 2018 so that the refocusing of existing development activities in APBD 2018 has been established in December 2017, the village conducted APBD in February 2018 which should be done in September 2018.

Cash Intensive Accountability begins with the planning stage, the implementation stage, the administration stage to the reporitng stage. At the implementation stage of Cash Intensive Village Fund in Kendal Village, Sekaran Sub-District of Lamongan Regency has applied the principle of accountability as well as the principle of Cash Intensive Work that has been in accordance with SKB 4 Minister and Regulation of the Domestic Minister No. 113 of 2014 concerning Village Financial Management which the implementation is independently involving workers from poor, unemployed and malnourished families as evidenced by the ID card of the villagers of Kendal. 
The reporting and accountability stage of the Village Fund and the Realization of the Implementation of APBD in Kendal Village, Sekaran Sub-District of Lamongan Regency have applied the principle of accountability and transparency. Reporting and accountability realization of the implementation of APBD has been based on Permendagri No. 20 year 2018. However, there are some problems, namely delays in the submission of accountability reports due to lack of knowledge and understanding and commitment from PKA responsible for managing activities.

\section{References}

Angelia, N., et al. (2020). Analysis of Community Institution Empowerment as a Village Government Partner in the Participative Development Process. Budapest International Research and Critics Institute-Journal (BIRCI-Journal). P. 1352-1359.

Bely, R.B D. (2015), Petunjuk pelaksanaan Bimbingan dan konsultasi Pengelolaan keuangan Desa. Deputi Bidang Pengawasan Penyelenggaraan Keuangan Daerah. BPKP.

Bungin, B. (2007). Penelitan Kualitatif. Jakarta: Prenada Meda Group.

Culla, A. S,. (2002). Masyarakat Madani, Pemikiran, Teori Dan Relevansinya Dengan Cita-Cita Demokrasi. Jakarta: Raja Grafindo Persada.

Deddi, N., I. S. Putra Dan M. Rahmawati. (2007). Akuntansi Pemerintahan. Jakarta: Salemba Empat.

Halim dan Y. Kusufi. (2012). Akuntansi Sektor Publik: Teori, Konsep dan Aplikasi. Jakarta: Salemba Empat.

Handoko, T. H. (1996). Manajemen. Yogyakarta: Penerbit BPFE UGM,

Kaho, Y. R. (1997). Prospek Otonomi Daerah Di Negara Republik Indonesia. Jakarta: PT. Gravindo Persada.

Kementerian Keuangan 2016. Kebijakan Pengalokasian Dan Penyaluran Dana Desa Tahun 2017. Disampaikan Pada Workshop Penyusunan Rancangan Peraturan Kepala Daerah Mengenai Tata Cara Perhitungan, Pembagian Dan Penetapan Rincian Dana Desa TA 2017. Redtop Hotel And Convention Center. 21-24 November 2016.

Lembaga Administrasi Negara Dan Badan Pengawasan Keuangan Dan Pembangunan RI 2003. Pengukuran Kinerja Instansi Pemerintah, Lembaga AdministrasiNegara dan BPKP, Jakarta.

Manulang. (1991). Dasar - Dasar Manajemen. Jakarta: Ghalia Indonesia.

Mardiasmo. (2002). Otonomi Daerah Dan Manajemen Keuangan Daerah. Yogyakarta: Andi.

Moe, T. M. (1984). The New Economics of Organization. American Journal of Political Science, 28, 737-777.

Moeljarto, T. (1995). Politik Pembangunan Sebuah Analisis, Konsep Arah dan Strategi. Yogyakarta: Tiara Wacana.

Moleong, L. J. (2002). Metode Penelitian Kualitatif. Bandung: Remaja Rosdakarya.

Ndraha, T. (2000), Ilmu Pemerintahan I \& II, BKU Ilmu Pemerintahan. Jakarta: Penerbit IIP.

Nugroho, R. (2003). Kebijakan Publik, Formulasi, Implementasi, Dan Evaluasi, PT Elek Media Komputindo. Jakarta: Kelompok Gramedia.

Peraturan Presiden Nomor 11 Tahun 2015 Tentang Kementerian Dalam Negeri;

Peraturan Pemerintah Nomor 43 Tahun 2014 Tentang Peraturan Pelaksanaan UU Nomor 6 Tahun 2014 Tentang Desa. 
Peraturan Presiden Nomor 12 Tahun 2015 Tentang Kementerian Desa, Pembangunan Daerah Tertinggal Dan Transmigrasi.

Peraturan Pemerintah Nomor 60 Tahun 2014 Tentang Dana Desa Yang Bersumber Dari APBN.

Peraturan Pemerintah Nomor 105 Tahun 2000 Tentang Pengelolaan Dan Pertanggungjawaban Keuangan Daerah.

Peraturan Menteri Dalam Negeri Nomor 113 Tahun 2014 Tentang Pengelolahan Keuangan Desa.

Peraturan Menteri Dalam Negeri Nomor 114 Tahun 2014 Tentang Pedoman Pembangunan Desa.

Peraturan Menteri Dalam Negeri Nomor 20 Tahun 2018 Tentang Pengelolahan Keuangan Desa.

Rasul, S. (2003). Pengintegrasian Sistem Akuntabilitas Kinerja Dan Anggaran Dalam Perspektif UU NO. 17/2003 Tentang Keuangan Negara. Jakarta: PNRI

Scott, W. R. (2009). Financial Accounting Theory. Fifth Edition. Canada: Prentice Hall.

Starling, G. (2008). Managing The Public Sector 8th Edition. Thompson Wadsworth. Boston, M.A. Jurnal Kebijakan \& Administrasi Publik JKAP 19(1)

Stigler, G. (1971). The Theory Of Economic Regulation. Bell Journal Of Economics And Management Science 3. Chicago: Rand Corporation.

Sugiyono. (2011). Metode Penelitian Kuantitatif, Kualitatif Dan R\&D. Bandung: Afabeta

Sugianto. (2007). Akuntansi Pemerintahan dan Organisasi Non Laba. Universitas Brawijaya Malang: PPAK.

Sujamto. (1996). Aspek-Aspek Pelaksanaan Otonomi Daerah. Jakarta: Bina Aksara.

Sulistiyani, A. T. (2004). Kemitraan Dan Model-Model Pemberdayaan. Yogyakarta: Gava Media.

Surat keputusan bersama 4 menteri ( SKB 4 Menteri ), 2018 Tentang padat karya tunai.

UUD 1945 Pasal 23C Mengenai Keuangan Negara

Undang Undang Nomor 6 Tahun 2014 Tentang Desa

Undang Undang Nomer 28 Tahun 1999 Tentang Penyelenggaraan Negara Yang bersih Dan Bebas Dari Korupsi, Kolusi dan Nepotisme

Wilson, J. dan H. Peter. (1993). Public Service \& The1990's, Issues in Public Service Finance and Management. Great Britain: Tudor Business Publishing. 